\title{
A Framework Prototype for E-Authentication of Iraqi Civil-Identity Certificate
}

\author{
Imad J. Mohamad ${ }^{1}$, Aws A. Abdulsahib ${ }^{2}$ \\ ${ }^{1}$ Dept. of Computer Science - College of Science \\ University of Baghdad/ Baghdad, Iraq \\ Dr.imadjm@scbaghdad.edu.iq \\ ${ }^{2}$ Sader-AlIraq College/ Baghdad, Iraq \\ awsnew@gmail.com
}

\begin{abstract}
Iraqi citizens in getting the advantages of e-government services, administration and democracy motivates us to study and look for how to expand the e-government project of Iraq with new e-services. The proposed framework considers a realistic problem in Iraq called the identity of the Civil Status. It verifies the (identity) validity of issued electronically instead of paperwork which takes significant time and effort to complete the transaction. An electronic interface is designed for the sake of the proposed framework using client-server approach assisted by PHP and MySQL software, intended to reduce the time and effort to improve job performance and provide interactive e-services to citizens. The developed e-service can be classified as Government to Citizen (G2C) type of e-Government.
\end{abstract}

Keywords: E-Authentication; E-Government in Iraq; E-Services.

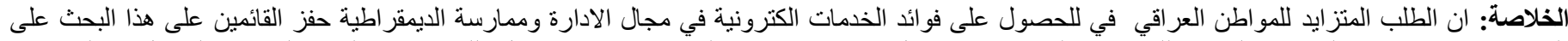

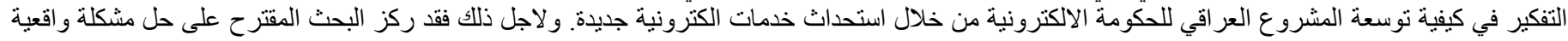

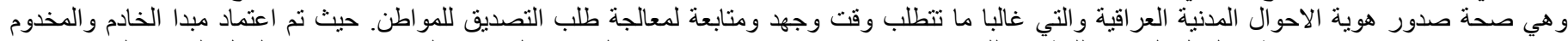

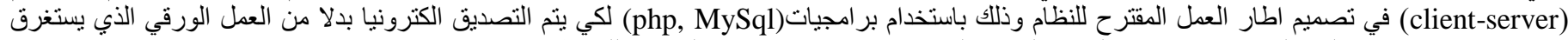
وقت وجهد كبير لانجاز المعاملة. ويمكن تصنيف الخدمة الجديدة المقترحة ضمن صنف خدمة الحكومة للمو اطن

\section{Introduction}

Governments are a dynamic mixture of aims, organization, structure and functions, and e-government initiatives are complex change efforts intended to use new and emerging technologies and techniques to assist a transformation in the operation and effectiveness of government. E-government is the continuous optimization of service delivery, constituency participation, and governance by transforming internal and external relationships through technology [1][2].

This research focuses on Iraq e-government status in terms of planning, problems, adopting and implementation. Typically, e-government is about applying information and information technology to all aspects of a government's business where it makes sense to improve efficiency and effectiveness in the achievement of policy and program outcomes.

Robert Schware, the professional from the World Bank, stated that the most effective way for successful e-government implementation is to construct a structured monitoring and evaluation system of progress made in achieving the objectives of the e-government programme, with a strong focus on inputs and indicators. Furthermore, e-government transforms and rationalizes public sector work through the use of ICT, which may include computer networking, the internet, mobile, computing, mobile telephony and the ability to connect all transaction stakeholders via the internet and through a standard interface [3].Recent studies show that investment in egovernment reduces corruption (and suggest that in fact egovernment is more effective than traditional administrative reform). Figure 1 shows an e-government project maturity. It explores the adoption benefits of e-government for government, business and citizens [3][4][5].

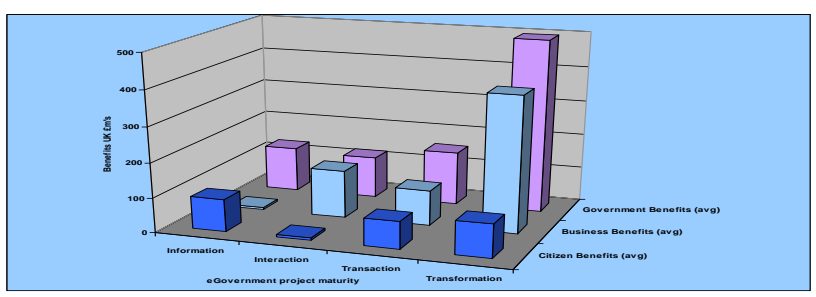

Figure1: Different benefits of e-government to stakeholders (OECD 2007) 
Many factors are affecting the progress of e-government implementation and adoption in the world including Iraq. Old Incomplete infrastructure of communication, corruption, lack of expertise, unscheduled work, unstandardized solutions, and conflicts with non-transparent politics and weak management of resources, some (if not all) of these factors may be considered reasons for failures (or delay) in Iraq e-government planning and implementation.

This research suggests guidelines with clear vision and willing for optimized Iraq e-government implementation and adoption. It focusses on the main obstacles that are standing against Iraqi ambitions for having modern technologies and better living environment. The Authentication of Iraqi civil identity certificate problem is the main concern of this research.

\section{Motivation}

The following are the motivations for current research:

- Looking for a solution for the authentication of government's certificates problem as a part of e-government services instead of the current time-consuming paperwork approach is the main motivation.

- Many claim high failure rate of e-government implementation and adaptation based on Word Bank statements and United Nations. Thus, the overcoming of these failure reasons is a challenge in terms of research and implementation.

- The increasing needs for Iraqi citizens in getting the advantages of e-government services, administration and democracy.

- Following up the world development in IT \& communication and looking for getting better QoS (quality of service) from Iraqi government to citizens.

\section{Problem Statement}

The identified Problem Statement for this study is called The Authentication of Iraqi civil-identity certificate.

During the last two decades, authentication of Iraqi-citizen certificate is required in many government offices of Iraq, and mostly consumes a lot of time and money from citizen either in getting government services or when applying for employment. In Iraq, we have many types of Certificate-Authentications. For examples, the authentication of graduate certificate is required as a starting process of: submitting for getting work position or employment, accepting new student at a school or and renew of passport. In addition, authentication of agent certificate in buying or selling of lands and houses are required as well.

\section{Background}

\section{A. E-Government Classification}

E-government can be classified into four categories [7][8]; government to citizens (G2C), government to business (G2B), government to government $(\mathrm{G} 2 \mathrm{G})$, and government to employees (G2E). In addition, three ingredients of egovernment are defined: e-administration, e-service, and edemocracy (Fig. 2).

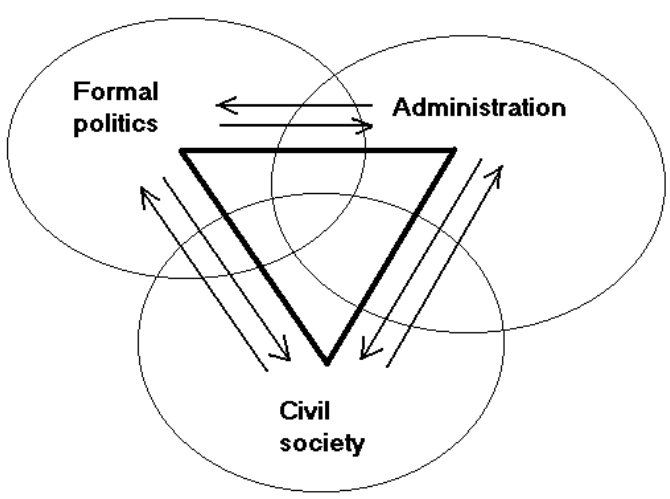

Figure 2: the three gradients of e-Government (OCED)

The scope of this work (Fig. 3) is limited to e-services that can support authentication of civil certificate for Iraqi citizen. Government to Government (G2G) and Government to Citizen (G2C) in terms of e-services are targeted.

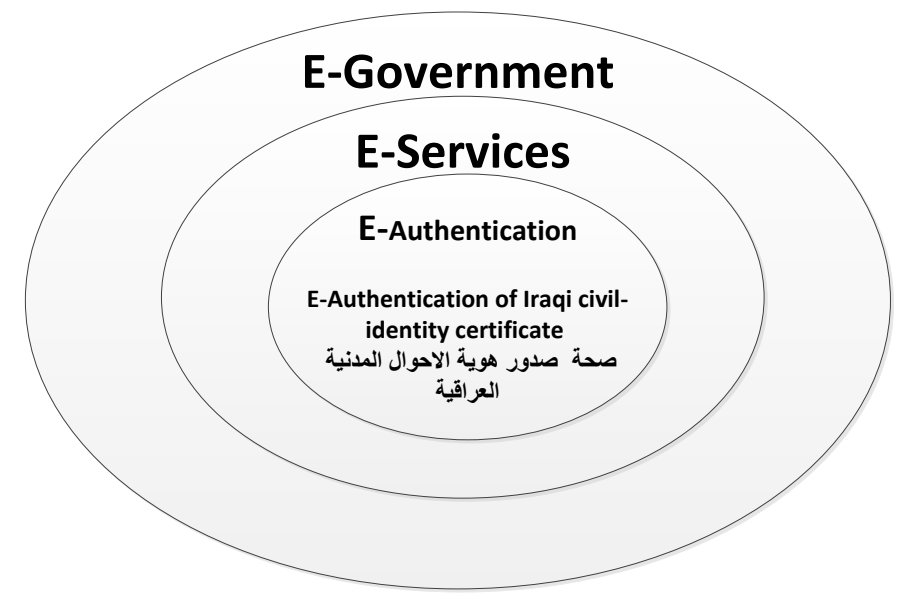

Figure 3: Paper Scope

\section{B. OECD E-Government taxonomy}

OECD (the Organization for Economic Co-operation and Development) was already identified four types of egovernment as taxonomy:

- Type 1. "Internet (online) service delivery".

- Type 2. "E-government is equated to the use of ICTs in government. While the focus is generally on the delivery of services and processing, the broadest definition encompasses all aspects of government activity". (Departmental back office reorganization included).

- $\quad$ Type 3. "E-government is defined as a capacity to transform public administration through the use of ICTs or indeed is used to describe a new form of government built around ICTs. This aspect is usually linked to Internet use" ("Joined-up", integrated government included).

- Type 4. "The use of ICTs, and particularly the Internet, as a tool to achieve better government". This is the only perspective taking a fundamentally external perspective; 
"better government" must be measured from outside, in terms of what good it does for society/citizens.

\section{Related Work}

Shafi's study [9] was identified the main factors effecting Qatar E-government implementation. The proposed model of the study investigated the gap between implementation and adoption for e-government services in terms of understanding and evaluation. For framework evaluation purposes, the study followed two measurement approaches: qualitative by survey and quantitative by interviews. The outcome of Shafi's study was five findings. The most two interested findings for us are: the conceptual models should be developed to assist the understanding and implementation of e-government services. While the second was pointed that per-institute internal and external sources should be considered in terms of organization, technological, society and politics themes from an institutional theory lens.

In Hana's study [10], an evaluation framework for Saudi Arabia e-government is proposed and investigated based on stages of e-services progress. The developed framework discussed the progressive stages of the Saudi ministries according to their e-government web site status and the faced obstacle. Five stages for e-government status are identified. Stage- 1 focused on web presence, stage- $2 \&$ stage- 3 validated the one-way interaction and two-way interaction respectively, stage 4 measured the transactions quantity, while the last one (stage 5) looked for integration to e-services. It was found that eight $(41 \%)$ of 21 ministries did not consider the main features of an e-government web site in terms of implementation. Ten ministries $(45.4 \%)$ were working in the first stage (web presence) either completely or partially; three ministries $(13.6 \%)$ were in the one-way interaction (the second stage); and six ministries working offline (had no online service at all). These findings clearly demonstrate that the evaluated ministries were lacked transactional services, weak average implementation for e-government services, resulting in citizen dissatisfaction and frustration.

An Analysis of Practices and Challenges for e-government in Egypt is discussed in Gebba's paper [11]. The research addressed the services provided by Egypt e-government to citizens, businesses, government employees and other bodies. The outcome shows good progress in Egypt but it is still lagging far behind other Arab countries, particularly Gulf countries that launched their e-government programs recently.

The development of E-Government in Sweden was discussed by Magnus Landgren [12]. Three stages for e-services are suggested and highlighted. Transparency stage (the 1st stage), to provide access to the existing records such as the property register, historical maps, diaries etcetera. Online application stage (the 2nd stage), in which a customer can play a role in eservice process. Interaction and authority stage (full participation, the 3rd stage), it provides advance sharing from customer to the online capabilities such as using voice and video conferences and using two way interaction facilities. Extra information can be offered to the customer for decision making after authentication step such as username/password.
In Ramli's study [13] the experience of E-Government in Malaysia is discussed using hybrid approach that may well suit the Malaysian government in managing e-government is discussed as well. The implementations of some Malaysian projects are overviewed such as: 1) "E-Syariah" to uphold the splendors of the Syariah court, e-syariah has been seen as a solution to enhance the quality and efficiency of public service delivery through the use of ICT. 2). E-land project, is one of egovernmentes flagship projects which was initiated by the Ministry of Natural Resources and Environment. It aims to develop an integrated, comprehensive and user-friendly land management and administration system to enhance the speed and quality of public service delivery. In E-Pemudah project, PEMUDAH is a short form for the Special Task Force to Facilitate Business, set up on 17 February 2007. It comprises representatives from both public and private sectors, with the aim of supporting Malaysiaes transition towards a knowledge driven economy.

The Effects of Website Quality on Adoption of E-Government Service is Palestinian, Jordan, and Saudi Arabia is studied in [14][15][16] respectively. The main conclusion for these studies are confirmed that the designers of e-government websites should take into considerations the construct elements (the quality of information, quality of service, and quality of the system when designing e-government websites because they affect users' intentions to use and consequently affect the success degree of e-government initiatives.

\section{The Proposed Framework: The Authentication of Iraq Civil-Identity Certificate}

The current limited interactive services in Iraq e-government motivated us to propose an e-solution for the authentication problem of civil-identity certificate instead of the current paperwork-based processing.

The following sub sections are discussing the current paperwork authentication requirements (steps) for the Iraq-civil identity certificate, and how the proposed framework is designed to support the equivalent e-service using interactivebased website.

In Iraq, many institutes are considering the authentication of civil-identity certificate in its processing to the civil transaction. For instance, the mentioned authentication process is required at the start of opening a file for each citizen in the following cases:

- The management of the primary school normally request from the student's parent to submit a new authenticated certificate civil identity as part of registration process for $1 \mathrm{st}$ year of study.

- The same authentication process should be followed when the student transfers from one school to another.

- Furthermore, the authentication of certified civil identity is required as a prior process in renew of General National Certificate Authentication process. 
Typically, the current paperwork sequence of the authentication process requires the following steps:

- $\quad$ Issuing a titled letter from the school to the authorized institute of civil-status identity.

- The student (parent) should go to the authorized institute to get the confirmed letter (the answer letter) of the authentication process.

- $\quad$ The student (parent) should wait in long queues inside the institute in order to get the authenticate certificate (the answer confirmed letter to the school).

- The parent (student) or a representative person from the institute should deliver the confirmed letter to the school.

The scenario for the proposed e-service to achieve the same goals of the equivalent paperwork-based process is shown in Figure 4.

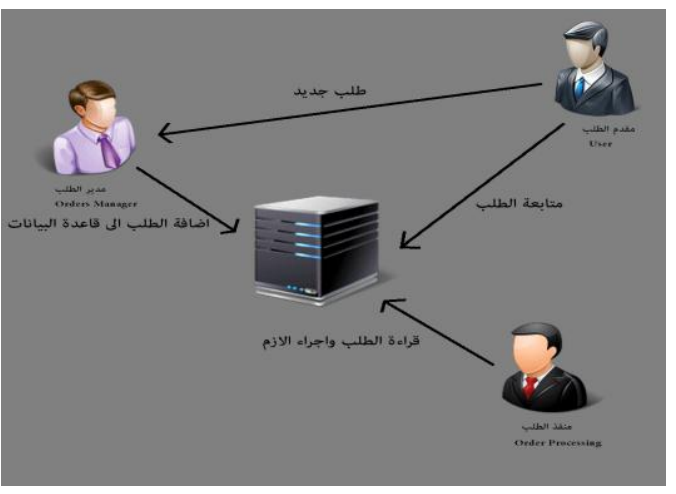

Figure 4: the proposed e-service scenario

In terms of software engineering principles, the following stages are followed in the design and implementation of the proposed framework:

1) Information Gathering phase: The websites of the ministries are used as a main source for the gathering of the information for the proposed system. Besides the interviews of the professionals, to collect the related forms that are used in paperwork process during the authentication process of civil identity at the government institute, and the personal investigation to validate the gathered information.

2) Requirements Analysis phase: The requirements analysis of the proposed system is evaluated according to the actual visiting to the responsible government institute. Therefore, the used forms in the authenticvation process are studied, then the sequence of the authentication process is noted, and finally the issuing requirements of the confirmed letter (official approval letter) are registered.

3) Design Phase (Data Base Design): Figure 5 shows the design of the proposed system using relational data base using MySql software and PHP programming language. The main elements in the proposed design include: (Identity,Order, Government, and Status) data base tables.

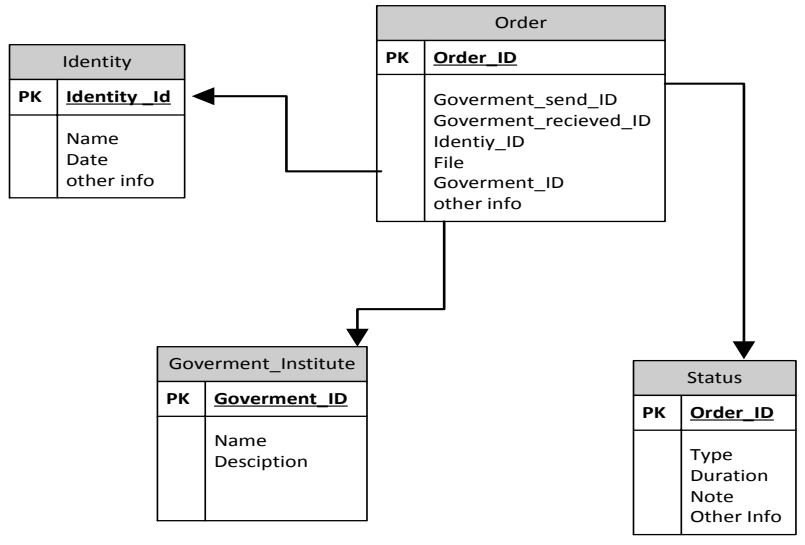

Figure 5 : The relational data base design for the proposed system

4) The Implementation Phase: The following are the software requirements used in the implementation phase of the proposed framework:

- $\quad$ Apache web server: Apache http has been the most popular web server on the Internet.

- $\quad$ PhP language: PHP is a widely-used general-purpose scripting language that is especially suited for Web development and can be embedded into HTML.

- MySql data base: The MySQL database server is the most popular open source database around. The "SQL" part of MySQL stands for "structured query language," which is a standard interactive and programming language for getting information from and updating a database.

The Client-server communication and the main software \& hardware elements of the proposed design are shown in Figure (6).

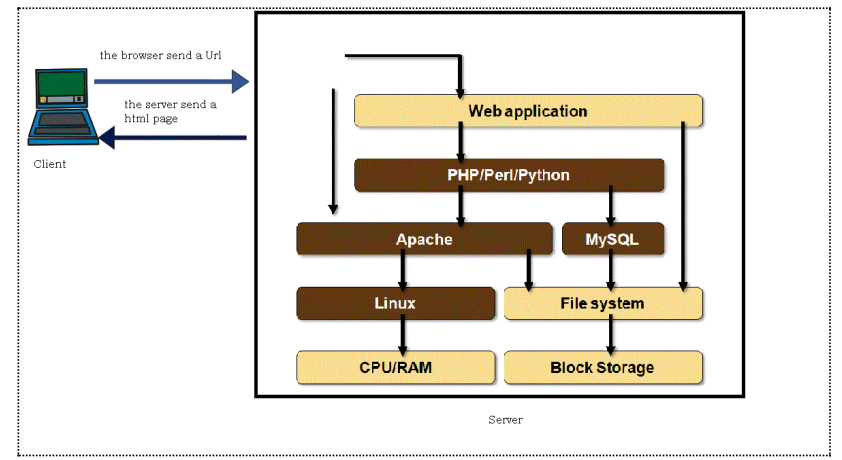

Figure 6 : The Client-Server Communication of the proposed system

Figure 7 shows the main database table of the design contains the information about civil-identity. The client queryform for the tracing of the status of the submitted transaction is shown in Figure 8. 


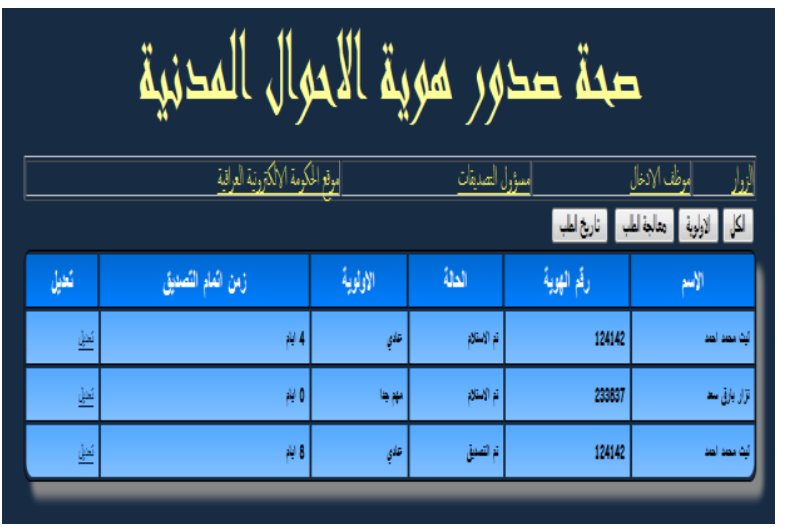

Figure 7: Employee page (in charge of authentication)

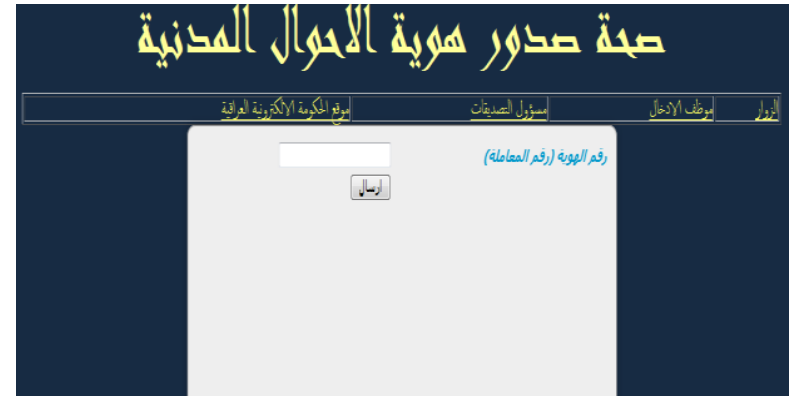

Figure 8 : Client query (tracing the order status)

The employee in charge of receiving the order of the authentication process can upload a copy of the citizen identity certificate for the citizen by clicking on browse button on form as shown in figure 9. Then the employee who will process the same order should change the status of the transaction as necessary. This status can be traced online by the citizen.

At the beginning of activating the system, the information of the civil identity record must be filled (feed into the system) by the employee per citizen using the form shown in Figure 9.

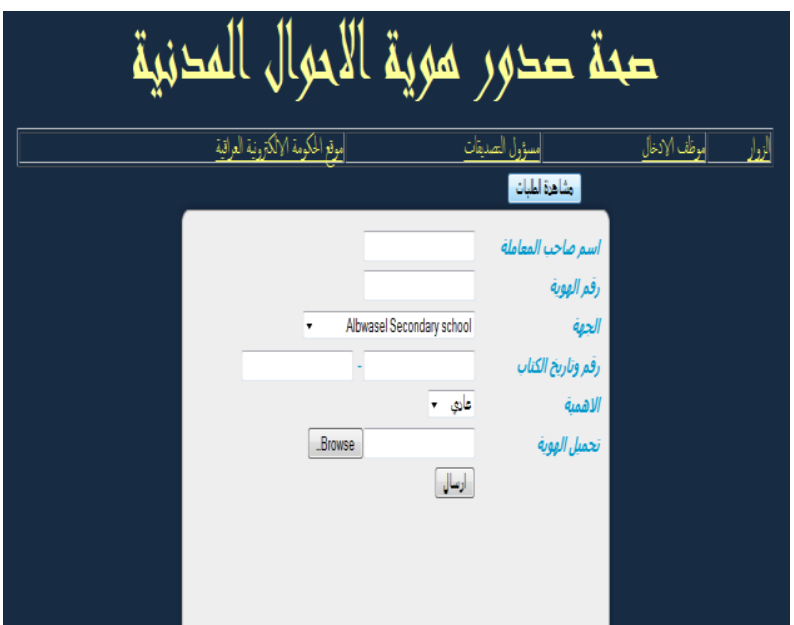

Figure 9 : Citizen civil-identity Information (Entry Page)

\section{Suggestions To Improve The Status Of Iraq E-Government}

After exploring the e-portal of Iraqi Ministries, doing interviews with e-government professionals, and the users (citizens), besides of the comparison of the available e-services to other world available e-services, ), the Status of EGovernment in Iraq can be summarized as follows:

- Most of the available e-services are of informationtype oriented compared to limited support of interactive-type oriented to the citizens.

- The need for upgrading of the ICT Infrastructure besides better deployment of e-government benefits in an enterprise e-Iraq package is required.

- The absence of the main gate or e-switch that is responsible for the management, connection, and monitoring of the e-government activates in Iraq. Therefore, from our point of view, the Iraq e-portal is not ready to play this superior role.

- The need of E-Culture for citizen and for the government employers as well, to understand and to deploy the importance of e-government to the Iraqi society.

- $\quad$ Looking for more interactive e-services and finding a new ways to encourage more citizen participation controlled by the managers in each individual ministry.

- Transparency in implementing and adopting the eservices is necessary to facilitate and to speed up the egovernment process in Iraq.

- E-Democracy should be considered to improve the participation of citizens in the new Iraq paradigms.

- Much more investigation is required to transit of the existing paperwork-based services to equivalent e-services, besides the consideration of quality of service.

- $\quad$ Updating of related regulations and policies to assist faster implementation of Iraqi e-government programs.

\section{Conclusion}

The main conclusions for the current research are:

- Transiting of e-services from the information-based to interactive-based type of should take more consideration as we noticed in the e-governments websites for other successful world experiences.

- The proposed e-authentication of civil-identity certificate can reduce the waiting time of the citizen, and will encourage more research for discovering more trends of eservices in Iraq.

- The client-server approach (and data centers) in the proposed e-services is supported by data base management system and it is expected from such systems to increase trust factor, the transparency, and the sharing of information between citizen and the institutes government. The gain is more trust, better facilities, saving time, and less cost for the transaction processing of citizen.

- The deployment of computer literacy in our society is necessary to achieve better implementation of E-government, 


\section{References}

[1] Palvia, S. C. J., \& Sharma, S. S. (2007). Egovernment and e-governance: definitions/domain framework and status around the world, International Conference on E-governance.

[2] Riad, A. M., El-Bakry, H. M., \& El-Adl, G. H., (2011), "E-government Frameworks Survey", International Journal of Computer Science, Vol. 8, Issue 3, No. 2, pp. 319-323.

[3] Schware, R., \& Deane, A. (2003). Deploying egovernment programs: The strategic importance of "I" before "E". info, 5(4), 10-19.

[4] Andersen, T.B., (2009), E-Government as an anticorruption strategy, Information Economics and Policy. vol. 21, no. 3, pp. 201-210. North-Holland.

[5] Grönlund, Å., Flygare, A-M, D., (2006), The Effect of eGovernment on Corruption: Measuring Robustness of Indexes. In Janssen et al. EGOV 2011, p 14-26.

[6] Shim, D.C., Eom, T.H., (2009), Anticorruption effects of information communication and technology (ICT) and social capital. International Review of Administrative Sciences. vol. 75, no. 1, pp. 99-116.

[7] Abanumy, A., Al-Badi, A., \& Mayhew, P. (2005). eGovernment Website accessibility: in-depth evaluation of Saudi Arabia and Oman. The Electronic Journal of e-Government, 3(3), 99-106.

[8] Alfarraj, O., Drew, S., \& AlGhamdi, R. (2012). EGovernment Stage Model: Evaluating the Rate of Web Development Progress of Government Websites in Saudi Arabia. arXiv preprint arXiv:1211.2406.

[9] Al-Shafi, S. H. (2009). Factors affecting eGovernment implementation and adoption in the State of Qatar. School of Information Systems, Computing and Mathematics, $(\mathrm{PhD}$, thesis).

[10] Al-Nuaim, H. (2011). An Evaluation Framework for Saudi E-Government. Journal of e-Government Studies and Best Practices, 2011.

[11] Gebba, T. R., \& Zakaria, M. R. (2012). E-government in Egypt: an analysis of practices and challenges. International Journal of Technology and Management (IJTM), 1(1).

[12] Magnus Landgren, Development of E-government in Sweden, , FIG Working Week 2012, Knowing to manage the territory, protect the environment, evaluate the cultural heritage, Rome, Italy, 6-10 May 2012.

[13] Ramli, R. M. Hybrid Approach of e-Government on Malaysian e-Government Experience. International Journal of Social Science and Humanity, Vol. 2, No. 5, September 2012.
[14] Jaber, N. O. A. (2011). Strategic Analysis and Development of Electronic Government Strategies for the Palestinian Municipalities (Doctoral dissertation, National University).

[15] Alshehri, Drew, Alhussain \& Alghamdi, (2012), The Effects of Website Quality on Adoption of EGovernment Service: An Empirical Study Applying UTAUT Model Using SEM, 23rd Australasian Conference On Information Systems, 3-5 Dec 2012, Geelong.

[16] Qutaishat, F. T. (2013). Users' Perceptions towards Website Quality and Its Effect on Intention to Use Egovernment Services in Jordan. International Business Research, 6(1), p97. 